\title{
Peta obletnica prve slovenske revije za izobrazevanje odraslìh
}

Revija Andragoška spoznanja, prva slovenska revija za izobraževanje odraslih, praznuje peto obletnico izhajanja. Člani uredniškega odbora se skupaj z avtorji in bralci veselimo tega jubileja. Pred očmi imamo začetna prizadevanja, da je revija sploh nastala, in nato prizadevanja za njen obstoj, pri pridobivanju novih sodelavcev, šrjenju kroga bralcev in zagotavljanju materialnih sredstev, pri čemer ne smemo pozabiti tudi na občasne težave. Večina truda pa je bila posvečena te$m u$, da bi revija opravljala svoje osnovno poslanstvo.

Uredniški odbor sestavljajo domači in tuji znanstveniki ter strokovnjaki. S prispevki sodelavcev s tujih univerz spremljamo razvoj stroke v evropskem merilu. Tudi domači sodelavci povezujejo revijo s tujimi dosežki, predvsem pa skrbijo, da je čim tesneje vpeta $v$ vzgojno-izobraževalno stvarnost.

Uredništvo je oblikovalo koncept revije glede na dane razmere. Ker je to edina revija za izobraževanje odraslih, naj bi bila strokovnoznanstvena: objavljala naj bi dosežke raziskav in strokovne prispevke iz prakse. S tem bi omogočala širši in boljši pretok strokovnega znanja o vzgoji in izobraževanju odraslih, razvoju človeških virov, o pospeševanju lokalnega in regionalnega razvoja in pripomogla k reševanju najbolj perečih družbenih problemov. Hitrejši in učinkovitejši prenos znanja je potreben na vseh področjih. Ni dejavnosti v družbi, kjer ne bi bilo vključeno tudi izobraževanje, bodisi v muzejih, zaporih, trgovini, proizvodnji, zavodih za zaposlovanje, planinskih društvih, trgovinah z računalniki bodisi v galerijah. Revija je tako po svo-

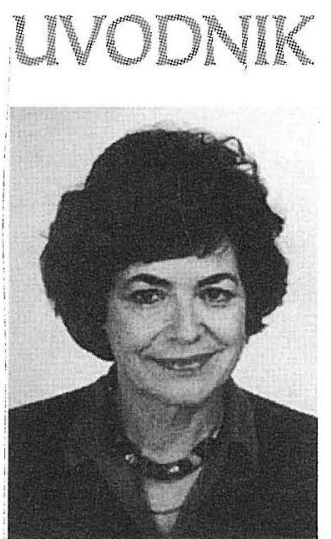

dr. Ana Krajnc jem osnovnem konceptu namenjena širokemu krogu bralcev.

Kaj nam pove pogled nazaj? Uredništvo je pritegnilo $k$ sodelovanju več kot 120 avtorjev $z$ različnih področij. Pogrešamo pa avtorje iz izobraževalnih centrov v podjetjih, zato bomo $\checkmark$ prihodnje posebno pozornost posvetili prav znanju za delo. Štiri številke na leto obsegajo povprečno 385 strani. Krog bralcev je glede na opravljeno raziskavo z anketnim vprašalnikom geografsko in tudi interesno zelo razpršsen. To narekuje uredništvu še posebne, nove naloge.

Revija Andragoška spoznanja je bila doslej vsebinsko osredotočena zlasti na najrazvitejša andragoška področja, pri nas do sedaj najbolj uveljavljena, ki so dala tudi največ spoznanj, kot so izobraževalni centri v podjetjih, ljudske univerze in oddelki za odrasle na rednih šolah ter študij na daljavo. Predstaviti je bilo treba to, kar je že razvito v praksi in tudi raziskano. Marsikaj, kar bi sicer ostalo izgubljeno po predalih, nam je s pomočjo revije uspelo dokumentirati in objaviti. Tako so se vrstili prispevki o uspelih primerih v praksi, razprave in povzetki iz raziskav, odmevi o dogodkih doma in na tujem ter sprotne informacije o slovenskih in mednarodnih konferencah. S prispevki v reviji smo v prvih petih letih spremljali razmah izobraževanja odraslih $v$ devetdesetih letih $v$ Sloveniji, privatizacijio izobraževalne dejavnosti in nastajajoče izobraževalne projekte, kot so 2.000 mladih raziskovalcev (Ministrstvo za znanost in tehnologijo), 5.000 mladih brezposelnih (Ministrstvo za delo, družino in socialno varnost), funkcionalna nepismenost (Andragoški cen- 
ter Slovenije), raziskovanje in premagovanje stereotipov o starejših (Univerza za tretje življenjsko obdobje), andragoška poletna šola (Filozofska fakulteta) in drugi. Izobraževalna dejavnost je vključena povsod, kjer se ljudje združujejo in delujejo. Tako se učna okolja dokaj hitro razraščjo. Paradigme andragogike pa se v prehodnem obdobju hitro spreminjajo.

Uredniška politika je bila v prvih petih letih namerno naravnana na nekatere temeljne naloge: dokumentirati in ohraniti dosedanja spoznanja, predstaviti najpomembnejša in najrazvitejša področja pridobivanja znanja odraslih, širiti strokovno andragoško znanje in s tem povečevati kakovost v praksi, na ljudskih univerzah, v izobraževalnih centrih $v$ podjetjih, enotah za odrasle pri rednih šolah in $v$ zasebnih andragoških ustanovah ter $v$ skupinah, v katerih se ljudje učijo skupaj in drug od drugega, dopolnjevati andragoško teorijo, pospeřevati in spodbujati raziskovanje, delno nadomestiti pomanjkljivo strokovno in študijsko literaturo ter posredovati pomembnejša spoznanja z vsega sveta in nas tako tudi mednarodno povezovati.

Prispevki so namenoma vključevali različne žanre: znanstvene razprave, strokovna poročila, odmeve iz prakse za prakso, informacije o konferencah, posvetih in knjižnih novostih. Tako je revija opravljala več funkcij hkrati, zajela je širši krog avtorjev in bralcev, od raziskovalcev, praktikov, ljudi, ki se v andragoško prakso šele vključujejo kot zunanji sodelavci, do drugih strokovnjakov, ki so z izobraževanjem in razvojem ljudi kakorkoli poveza$n i$.

Obletnice so čas, ko moramo misliti tudi na prihodnost. Uredništvo si za naslednja leta postavlja jasen koncept delovanja in nove naloge. V prihodnje bo dejavnost revije bolj osredotočena na nova področja učenja, kot so pridobivanje funkcionalne pismenosti, povečanje zaposljivosti ljudi, razvijanje kompe- tentnosti posameznikov, znanje za mednarodno sodelovanje, lokalni in regionalni razvoj in prestrukturiranje gospodarstva, zagotavljanje resnične vseživljenjskosti izobraževanja, pa tudi pravice do enakih možnosti za vse. Uvajanje inovacij v izobraževanje odraslih bi pospešilo kulturni, socialni in ekonomski razvoj. Pred nami so nekatera nerešena vprašanja. Kako in kje se ljudje pripravljajo in usposabljajo za demokratične odnose ter vlogo dejavnega državljana? Kje se učijo živeti v skupnosti? Kako lahko dohajajo nagli razvoj in kje se usposabljajo za socialne vloge? Izobraževanje zapornikov ne bi smelo biti nedotakljiva tema, zato želimo pritegniti čim več ljudi, ki se ukvarjajo s tem vprašanjem. Tudi funkcionalna nepismenost manj izobraženega prebivalstva je precejšen problem celotne naše družbe, in ne le posameznika. Preprečuje, da bi od kvantitete dela prešli h kvaliteti. Premagujejo jo lahko samo prostovoljno mentorstvo, izobraževanje kot socialno gibanje, intenzivnejša kulturna dejavnost na lokalni ravni, decentralizacija $v$ vsakem pogledu in nove možnosti za druženje ljudi. Odpravljanje funkcionalne nepismenosti ni šola, temveč izobraževalno gibanje ali, še bolje, različna izobraževalna gibanja: gibanje posameznikov, društev. Zahteva pa tudi sodelovanje osveščenih podjetij, socialnih centrov, vojske, države. Je podlaga za lokalni in nacionalni razvoj. Mladi, ki jih izloča šolski sistem, so odvisni od uvajanja inovacij v andragoško prakso, kot sta odprt dostop do izobraževanja in študij na daljavo. V prihodnje ne bo veliko mesto mesto z velikim številom prebivalcev, temveč manjše mesto z visoko izobraženimi prebivalci. Starejši, od starejših delavcev do starostnikov, invalidne osebe in drugi so še zmeraj premalo ali sploh niso vključeni $v$ vseživljenjsko izobraževanje.

Pričakujemo, da bo jasen koncept in načrtno delovanje pritegnilo $k$ pisanju nove sodelavce. Tematiko želimo interdisciplinarno pove- 
5

zati in s tem širiti krog bralcev ter povečati uporabnost znanja.

$V$ reviji ne iščemo dokončnih odgovorov. V̌̌asih je teže postavljati prava vprašanja, koł pa odgovarjati. Podpirali bomo tudi polemičnost in drugačno, izvirno razmišljanje.

Prevodi seznanjajo bralce s tujimi spoznanji in s tem približujejo tuja in naša merila pri prenašanju znanja in razvoja, saj ne želimo $v$ ničemer zaostajati. V nas je namreč še veliko optimizma in navdušenja za razvoj stroke, znanstveno raziskovanje in medsebojno sodelovanje doma in na tujem.

Ob peti obletnici se zahvaljujemo tudi Ministrstvu za šolstvo in šport, Ministrstvu za znanost, Nemški zvezi ljudskih visokih šol iz Bonna in Znanstvenemu inštitutu Filozofske fakultete, ki so tudi finančno omogočili izhajanje revije.V prihodnosti želimo revijo še bolj približati nekaterim razvojnim projektom v Sloveniji.

tolonekrine

AS 112020 